\title{
What is the optimal cut-off point for low coronary artery calcium score assessed by computed tomography? Multi-Detector Computed Tomography ANIN Registry
}

Jaki jest optymalny punkt odcięcia niskiego indeksu zwapnień tętnic wieńcowych? Multi-Detector Computed Tomography ANIN Registry

\author{
Edyta Kaczmarska ${ }^{1}$, Cezary Kępka ${ }^{1}$, Zofia Dzielińska ${ }^{1}$, Radosław Pracoñ ${ }^{1}$, Karolina Kryczka ${ }^{1}$, Joanna Petryka ${ }^{1}$ \\ Jerzy Pręgowski², Mariusz Kruk', Marcin Demkow ${ }^{1}$
}

1Department of Coronary and Structural Heart Diseases, Institute of Cardiology, Warsaw, Poland

2Department of Interventional Cardiology and Angiology, Institute of Cardiology, Warsaw, Poland

Postep Kardiol Inter 2013; 9, 1 (31): 9-15 DOI: 10.5114/pwki.2013.34024

\begin{abstract}
Aim: This prospective study was conducted to evaluate the incidence and predictors of coronary artery disease (CAD) in relation to the low coronary artery calcium (CAC) score among patients with intermediate probability of CAD.

Material and methods: A total of 1132 consecutive patients were included in the analysis ( $58.7 \pm 10.9$ years, $46.7 \%$ males). Coronary computed tomography (CCT) angiography was performed in a multi-detector computed tomography scanner. Coronary artery calcium score was calculated by the Agatston method. Obstructive CAD was defined as the presence of coronary artery stenosis $\geq 50 \%$ on CCT angiography.

Results: Coronary artery disease was diagnosed in nearly one-fourth of patients $(n=272,24 \%)$. In the receiver operating characteristics (ROC) curve analysis a CAC score of 10 was used as an optimal cut-off point for discriminating obstructive CAD (sensitivity: 0.79 , specificity: $0.75, p<0.0001$ ) whereas for a CAC score of 100 the sensitivity and specificity were 0.48 and 0.92 , respectively. On multivariate analysis after adjustment for age, gender, hypertension, hyperlipidemia, creatinine levels, only in patients with CAC score $\leq 10$ age $(\mathrm{OR}=1.05,95 \% \mathrm{Cl}: 1.02-1.08, p=0.0005, \mathrm{OR}=1.05,95 \% \mathrm{Cl}: 1.03-1.08, p<0.0001)$ and male gender $(\mathrm{OR}=3.45$, $95 \% \mathrm{Cl}: 1.92-6.22, p<0.0001)$, likewise in group with CAC score $\leq 100$ age $(\mathrm{OR}=1.05,95 \% \mathrm{Cl}: 1.03-1.08, p<0.0001)$ and male gender $(\mathrm{OR}=3.31,95 \% \mathrm{Cl}: 1.88-5.81, p<0.0001)$ were independent predictors of obstructive CAD.

Conclusions: The cut-off point of 10 for CAC score determined patients with CAD with the best sensitivity and specificity. Therefore, a total CAC score < 10 should be classified as "low". In patients with a low CAC score obstructive high risk plaques prone to rupture are presented and are associated with increasing age and male gender.
\end{abstract}

Key words: coronary artery calcium score, coronary computed tomography, coronary artery disease.

\section{Streszczenie}

Cel: Zdefiniowanie punktu odcięcia dla niskiego indeksu zwapnień tętnic wieńcowych (coronary artery calcium - CAC) oraz ocena częstości występowania choroby wieńcowej (coronary artery disease - CAD) i jej predyktorów w grupie pacjentów z niskim indeksem CAC.

Materiał i metody: Analizie poddano 1132 kolejnych pacjentów (58,7 £10,9 roku, 46,7\% mężczyzn), u których wykonano wielorzędową tomografię komputerową tętnic wieńcowych. Indeks CAC obliczono półautomatycznie, stosując metodę Agatston. Chorobę wieńcową zdefiniowano jako obecność istotnego zwężenia ( $\geq 50 \%)$ w obrazie angiograficznym tomografii komputerowej.

Wyniki: Chorobę wieńcową rozpoznano u 24\% pacjentów $(n=272)$. Na podstawie krzywej ROC punkt odcięcia 10 dla indeksu CAC charakteryzował się najwyższą czułością i specyficznością w przewidywaniu choroby wieńcowej (AUC =0,84, czułość 0,79, specyficzność $0,75, p<0,0001)$, natomiast w przypadku indeksu CAC 100 czułość i specyficzność wyniosły odpowiednio 0,48 i 0,92. W analizie wieloczynnikowej - uwzględniającej wiek, płeć, nadciśnienie, hiperlipidemię, stężenie kreatyniny - w grupie CAC $\leq 10$ wiek $(O R=1,05$, $95 \% \mathrm{Cl}: 1,02-1,08, p=0.0005)$ i płeć męska (OR = 3,45, 95\% Cl: 1,92-6,22, $p<0,0001)$, a także w grupie pacjentów z CAC $\leq 100$ wiek $(\mathrm{OR}=1,05,95 \% \mathrm{Cl}: 1,03-1,08, p<0,0001)$ i płeć męska $(\mathrm{OR}=3,31,95 \% \mathrm{Cl}: 1,88-5,81, p<0,0001)$ były niezależnymi predyktorami wystąpienia CAD.

Corresponding author/Adres do korespondencji:

Edyta Kaczmarska MD, Department of Coronary and Structural Heart Diseases, Institute of Cardiology, 42 Alpejska St, 04-628 Warsaw, Poland, tel.: +48 2234343 42, e-mail: edytaka@gmail.com

Received: 14.01.2013, accepted: 28.01.2013. 
Wnioski: Punkt odcięcia 10 indeksu CAC z najlepszą czułością i specyficznością określa wystąpienie CAD. Indeks CAC $<10$ powinien być sklasyfikowany jako niski. W grupie z niskim indeksem CAC obecność istotnych, nieuwapnionych zwężeń wiąże się ze starszym wiekiem oraz płcią męską.

Słowa kluczowe: indeks zwapnień tętnic wieńcowych, tomografia komputerowa tętnic wieńcowych, choroba wieńcowa.

\section{Introduction}

Coronary computed tomography (CCT) has been approved for direct, noninvasive imaging of the coronary artery. Contrast-enhanced CCT angiography evaluates stages of atherosclerosis, demonstrates the percentage of luminal stenosis and provides an opportunity for identifying calcified and noncalcified components within coronary plaques. The coronary artery calcium (CAC) score, assessed on CCT at the first scan without contrast enhancement, is highly specific for atherosclerosis, and occurs only in the intima. The CAC score is a marker of the extent of coronary calcified atherosclerotic plaques. A high CAC score is predictive for obstructive coronary artery disease (CAD); therefore patients with low CAC scores are generally considered as those at very low risk of CAD and are referred to as low risk patients. Furthermore, as the absence of CAC is highly predictive of the absence of coronary artery stenosis, low CAC score has been proposed as an effective diagnostic tool for ruling out CAD [1-6].

The incidence and clinical relevance of $C A D$ in patients with low CAC scores are unclear. Recent studies involving CCT angiography have reported that negative CAC does not exclude significant coronary artery stenosis. Among those study populations with low or negative CAC scores, CAD was reported in considerably different incidences [7-11]. The incidence of CAD depended mainly on the patient population and on cut-off points applied for a low CAC score. Some studies evaluate CAD incidence with the applied cut-off for a low CAC score as 100, whereas a few analyses assign the cutoff as 10. In fact, the current guidelines and expert consensus for CCT assessment do not provide a definition of low CAC score $[1-3,5,12]$.

The leading issue is to distinguish patients with minor calcifications and CAD from patients with severe calcifications, since it has been established that non-calcified plaques or plaques with very low calcification are vulnerable and prone to rupture, whereas severe calcifications are generally interpreted as a kind of plaque stabilization [13, 14].

\section{Aim}

In this context, the present study investigated the incidence and predictors of obstructive CAD in CCT angiography in relation to low CAC score in intermediate risk persons.

\section{Material and methods}

\section{Study population}

There were 1132 consecutive patients identified from the prospective ANIN-CCT registry, referred for CCT angiography at the Department of Coronary and Structural Heart Dis- eases between January 2009 and December 2010. Contrastenhancement CCT scans were performed in patients with a history of (1) atypical angina and abnormal stress tests, (2) typical angina and negative stress tests. Each patient provided a written statement of informed consent for the diagnostic procedures performed.

\section{Demographic and cardiovascular risk factors}

Basic clinical data, including age, gender, hypertension, hyperlipidemia, diabetes, smoking history, and family history of CAD, were all prospectively determined at the time of the scan. Patients with a history of percutaneous angioplasty or surgical revascularization, valve surgery, history of myocardial infarction, or congestive heart failure were excluded from the analysis. Hypertension was defined as systolic blood pressure over 140 and/or diastolic blood pressure over $90 \mathrm{~mm}$ $\mathrm{Hg}$ and/or use of blood pressure-lowering medication. Hyperlipidemia was defined as elevated total cholesterol $>5.2 \mathrm{mmol} / \mathrm{l}$, low-density lipoprotein $(\mathrm{LDL})>2.59 \mathrm{mmol} / \mathrm{l}$, or triglycerides (TG) $>1.65 \mathrm{mmol} / \mathrm{l}$ and/or low high-density lipoprotein $(\mathrm{HDL})<1.15 \mathrm{mmol} / \mathrm{l}$ and/or use of lipid-lowering therapy. Diabetes was defined as present if the participant used insulin or oral hypoglycemics or if the glucose level exceeded $200 \mathrm{mg} / \mathrm{dl}(11.0 \mathrm{mmol} / \mathrm{l})$ for a single blood sample. Cigarette smoking was reported as ever (past and/or current use). A patient was considered to have a positive family history if a first degree relative had a history of coronary heart disease or stroke at an age of $<65$ years.

\section{CAC scoring and CCT angiography}

All CCT scans were performed at the Institute of Cardiology with a dual-source computed tomography scanner (Somatom Definition, Siemens, Forchheim, Germany) after single sublingual administration of nitrates. Non-contrast enhanced scans with 100- to 120-kV tube voltage were performed to calculate the CAC score prior to CCT angiography. Contrast-enhanced scans were then performed using a bolus of iodinated contrast medium $(80 \mathrm{ml}$ to $120 \mathrm{ml}$, Iomeron 400, Bracco Altana Pharma, Konstanz, Germany). The CAC score was manually marked by the operator and automatically calculated using the Agatston scoring method [15]. The measurements of CAC score involved the left main coronary artery (LMCA), the left anterior descending (LAD), the left circumflex (Cx) and the right coronary artery (RCA). The total CAC score was determined by summing CAC scores for all coronary arteries. The total CAC scores were categorized as $\leq 10,11-100$ and $>100$.

The finest quality images for all coronary segments were obtained from datasets reconstructed routinely in mid- to 
end-systole and diastole with retrospective electrocardiogram gating. The percent stenosis was calculated as the narrowest diameter of the lumen divided by the normal lumen diameter of the nearest normal proximal portion of the same segment in CCT angiography. Obstructive CAD was defined as stenosis $\geq 50 \%$ of the main coronary arteries.

\section{Statistical analysis}

All continuous data are expressed as mean \pm standard deviation (SD) and were compared using the Student $t$ test or one-way analysis of variance (ANOVA) as appropriate. Categorical data are presented as frequencies and were compared using the $\chi^{2}$ test. Independent predictors of CAD were identified using multiple logistic regression with the odds ratio (OR) and 95\% confidence interval (Cl). Receiver operating characteristics (ROC) curve analysis with area under the curve (AUC) was used to assess the relation of total CAC score to CAD prediction. Significance was assumed at the two-tailed $p$ value of $<0.05$. The data analysis was performed using SPSS 9.0 (Chicago, IL, USA).

\section{Results}

The study group consisted of 1132 patients (46.7\% men). The mean age was $58.7 \pm 10.9$ years. Baseline characteristics of the study population are presented in Table 1 . Hypertension and hyperlipidemia were observed in half of the study population. Over one-fourth of the patients had ab-

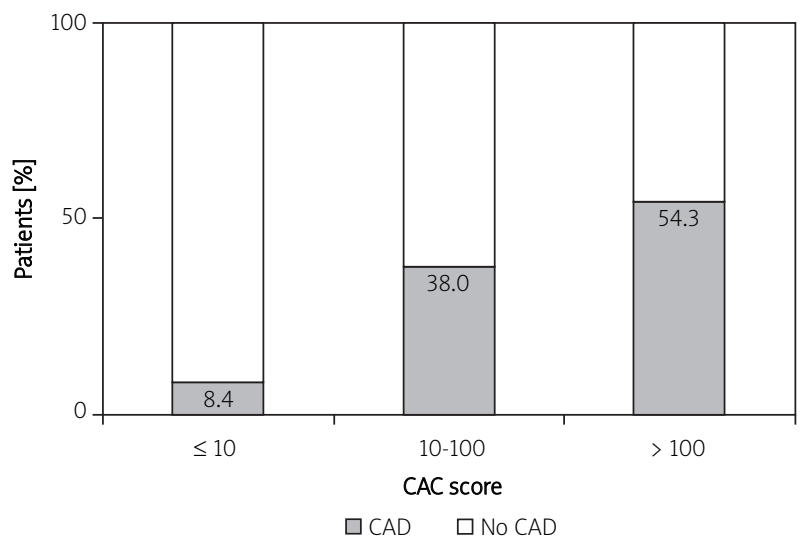

Fig. 1. The relation of increasing prevalence of obstructive CAD with increasing CAC score in the group studied $(n=1132)$

Ryc. 1. Wzrost częstości występowania CAD w grupach z podwyższonym indeksem CAC $w$ badanej grupie $(n=1132)$

normal low HDL levels. Diabetes was observed in 7.3\%. Smoking history was reported by one-fifth of the patients. Coronary artery disease was diagnosed in nearly one-fourth of the study group ( $n=272,24 \%)$.

A total CAC score $\leq 10,10-100$, and $>100$ was found in 668 (59.0\%), 221 (19.5\%), and 243 (21.5\%) patients, respec-

Table 1. Baseline characteristics of 1132 patients and association of CAC score with cardiovascular risk factors Tabela 1. Wyjściowa charakterystyka 1132 pacjentów oraz rozkład czynników ryzyka w zależności od wartości indeksu CAC

\begin{tabular}{|c|c|c|c|c|c|}
\hline \multirow[t]{2}{*}{ Parameter } & \multirow{2}{*}{$\begin{array}{l}\text { Study group } \\
\qquad(n=1132)\end{array}$} & \multicolumn{3}{|c|}{ CAC score } & \multirow[b]{2}{*}{$\begin{array}{c}>100 \\
(n=243)]\end{array}$} \\
\hline & & $\begin{array}{c}\leq 10 \\
(n=668)\end{array}$ & $\begin{array}{l}10 \text { to } 100 \\
(n=221)\end{array}$ & Value of $p$ & \\
\hline Age [year] & $58.7 \pm 10.9$ & $55.34 \pm 10.7$ & $61.97 \pm 9.2$ & 0.000 & $64.8 \pm 9.2$ \\
\hline Gender (male) & 46.7 & 39.8 & 48.6 & 0.023 & 64.2 \\
\hline Hypertension & 54.5 & 52.7 & 57.7 & NS & 56.8 \\
\hline Diabetes & 7.3 & 5.8 & 8.6 & NS & 10.3 \\
\hline Smoking & 21.8 & 19.3 & 25.9 & NS & 23.5 \\
\hline Family history of CAD & 52.6 & 26.5 & 20.4 & NS & 21.0 \\
\hline Hyperlipidemia & 24.1 & 51.5 & 53.2 & NS & 55.1 \\
\hline Creatinine $[\mathrm{mmol} / \mathrm{l}]$ & $77.9 \pm 17.8$ & $75.38 \pm 16.5$ & $79.47 \pm 16.7$ & 0.003 & $84.63 \pm 19.9$ \\
\hline Fasting glucose $[\mathrm{mmol} / \mathrm{l}]$ & $5.93 \pm 1.41$ & $5.8 \pm 1.2$ & $6.0 \pm 1.7$ & NS & $6.12 \pm 1.5$ \\
\hline Total cholesterol [mmol/l] & $4.96 \pm 1.15$ & $5.00 \pm 1.1$ & $5.04 \pm 1.2$ & NS & $4.73 \pm 1.2$ \\
\hline $\mathrm{HDL}[\mathrm{mmol} / \mathrm{l}]$ & $1.47 \pm 1.02$ & $1.55 \pm 1.2$ & $1.41 \pm 0.4$ & NS & $1.31 \pm 0.4$ \\
\hline $\mathrm{HDL}(<1.15 \mathrm{mmol} / \mathrm{l})$ & 26.7 & 20.55 & 30.22 & 0.025 & 38.2 \\
\hline TG [mmol/l] & $1.50 \pm 0.95$ & $1.40 \pm 0.9$ & $1.58 \pm 0.9$ & 0.055 & $1.63 \pm 1.0$ \\
\hline TG $(>2.3 \mathrm{mmol} / \mathrm{l})$ & 12.3 & 8.5 & 14.4 & 0.050 & 13.8 \\
\hline LDL [mmol/l] & $3.17 \pm 1.05$ & $3.20 \pm 1.0$ & $3.25 \pm 1.1$ & NS & $3.02 \pm 1.1$ \\
\hline CAD & 24.0 & 8.4 & 38.0 & 0.000 & 54.3 \\
\hline
\end{tabular}

Values are reported as proportion with condition (\%); continuous variables are reported as mean ( \pm SD) 


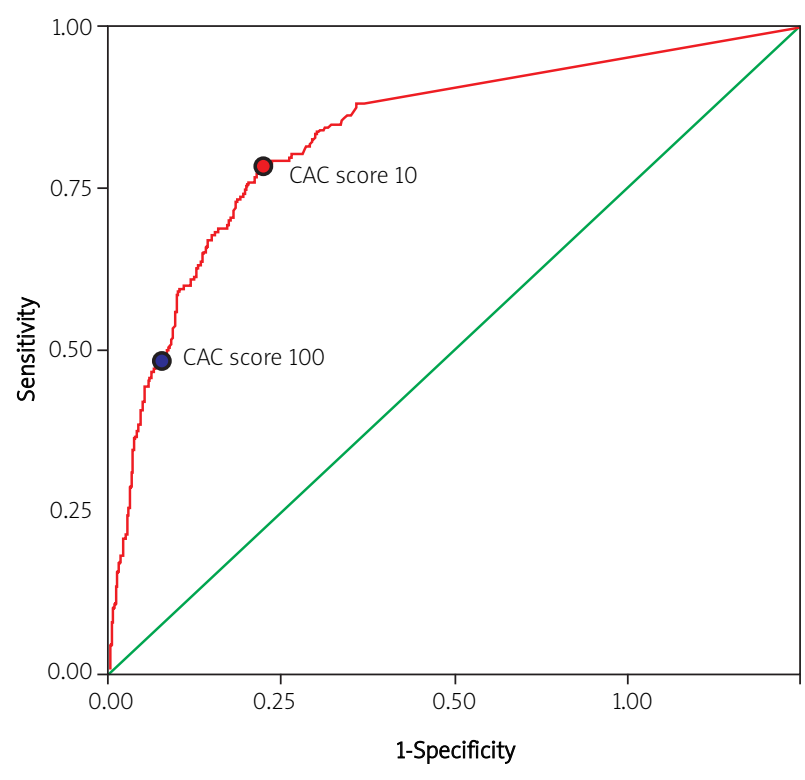

$A \cup C=0.84$, cut-off point CAC score 10 with sensitivity: 0.79 , specificity: 0.75 ; cut-off point CAC score 100 sensitivity: 0.48 specificity: 0.92; $p<0.0001$

Fig. 2. The ROC curve in the entire group for CAC score to predict obstructive CAD

Ryc. 2. Wykres krzywej ROC dla indeksu CAC w przewidywaniu wystapienia CAD w badanej grupie tively. We observed a stepwise increase in the incidence of CAD with increasing CAC score (Figure 1). Interestingly, there was an $\sim 5$-fold difference in rates of CAD between those with CAC scores $\leq 10$, and $10-100$ (8.4\% vs. 38.0\%, $p<0.0001)$. Patients' characteristics, depending on the cut-off points applied (< 10 vs. 10-100) for CAC score, are presented in Table 1. Patients with higher CAC scores (10-100), in comparison to patients with lower CAC scores $(\leq 10)$, were older, more frequently male, with significantly higher serum creatinine levels. Patients with CAC scores of 10-100 significantly more frequently present with inappropriate low $\mathrm{HDL}$ and high triglycerides levels (Table 1).

For the entire group the ROC curve for total CAC score and obstructive $(\geq 50 \%)$ coronary artery stenosis showed an AUC of 0.84, $p<0.0001$ (Figure 4). Based on the ROC curve, CAC score of $9.8(\approx 10)$ presented as an optimal cutoff point for discriminating obstructive CAD (sensitivity: 0.79 , specificity: 0.75 ). Yet, when the cut-off was upgraded to 100 , the sensitivity and specificity were 0.48 and 0.92 , respectively.

Table 2 presents characteristics of the patient populations with the CAC score $\leq 10$ and $\leq 100$ according to the presence of CAD. Similarly in both groups (CAC score $\leq 10$ and $\leq 100$ ) CAD was present among older males with hypertension, smoking history, hyperlipidemia, and higher creatinine levels. Univariate analysis was performed to determine predictors of CAD in CCT angiography in patients with CAC score $\leq 10$ and those with CAC score $\leq 100$. Results are presented in

Table 2. Relation of clinical covariates to CAC score and presence of CAD

Tabela 2. Rozkład zmiennych klinicznych w zależności od wielkości indeksu CAC i obecności CAD

\begin{tabular}{|c|c|c|c|c|c|c|}
\hline \multirow[t]{3}{*}{ Parameter } & \multicolumn{6}{|c|}{ CAC score } \\
\hline & \multicolumn{3}{|c|}{$\leq 10(n=668)$} & \multicolumn{3}{|c|}{$\leq 100(n=889)$} \\
\hline & $\begin{array}{c}\text { With CAD } \\
n=56 \\
(8.4 \%)\end{array}$ & $\begin{array}{l}\text { Without CAD } \\
\begin{array}{c}n=612 \\
(91.6 \%)\end{array}\end{array}$ & Value of $p$ & $\begin{array}{c}\text { With CAD } \\
n=140 \\
(15.7 \%)\end{array}$ & $\begin{array}{c}\text { Without CAD } \\
n=749 \\
(84.2 \%)\end{array}$ & Value of $p$ \\
\hline Age [year] & $59.5 \pm 10.62$ & $55.0 \pm 10.60$ & 0.002 & $61.57 \pm 9.9$ & $56.14 \pm 10.7$ & $<0.001$ \\
\hline Gender (male) & 60.7 & 37.6 & 0.001 & 56.4 & 39.1 & $<0.001$ \\
\hline Hypertension & 69.6 & 50.9 & 0.008 & 63.6 & 51.8 & 0.01 \\
\hline Diabetes & 8.9 & 5.6 & NS & 8.6 & 6.2 & NS \\
\hline Smoking & 28.6 & 18.9 & NS & 29.3 & 19.4 & 0.012 \\
\hline Family history of CAD & 30.4 & 26.1 & NS & 25.0 & 25.1 & NS \\
\hline Hyperlipidemia & 64.3 & 50.2 & 0.050 & 60.0 & 50.1 & 0.034 \\
\hline Creatinine $[\mathrm{mmol} / \mathrm{l}]$ & $82.711 \pm 16.29$ & $73.83 \pm 16.14$ & $<0.001$ & $81.69 \pm 16.7$ & $75.3 \pm 16.4$ & $<0.001$ \\
\hline Fasting glucose $[\mathrm{mmol} / \mathrm{l}]$ & $6.21 \pm 1.44$ & $5.72 \pm 1.04$ & 0.012 & $5.92 \pm 1.2$ & $5.83 \pm 1.3$ & NS \\
\hline Total cholesterol [mmol/l] & $4.99 \pm 1.01$ & $5.03 \pm 1.07$ & NS & $4.96 \pm 1.1$ & $5.03 \pm 1.1$ & NS \\
\hline $\mathrm{HDL}[\mathrm{mmol} / \mathrm{l}]$ & $1.41 \pm 0.47$ & $1.58 \pm 1.36$ & NS & $1.35 \pm 0.4$ & $1.55 \pm 1.2$ & NS \\
\hline $\mathrm{HDL}(<1.15 \mathrm{mmol} / \mathrm{l})$ & 32.4 & 19.2 & 0.077 & 31.9 & 21.3 & 0.039 \\
\hline $\mathrm{TG}[\mathrm{mmol} / \mathrm{l}]$ & $1.46 \pm 0.66$ & $1.41 \pm 0.95$ & NS & $1.53 \pm 0.9$ & $1.42 \pm 0.9$ & NS \\
\hline TG $(>2.3 \mathrm{mmol} / \mathrm{l})$ & 8.8 & 8.2 & NS & 9.8 & 11.0 & NS \\
\hline LDL [mmol/l] & $3.19 \pm 0.96$ & $3.19 \pm 0.99$ & NS & $3.21 \pm 0.9$ & $3.21 \pm 1.0$ & NS \\
\hline
\end{tabular}

Values are reported as proportion with condition (\%); continuous variables are reported as mean $( \pm S D)$ 

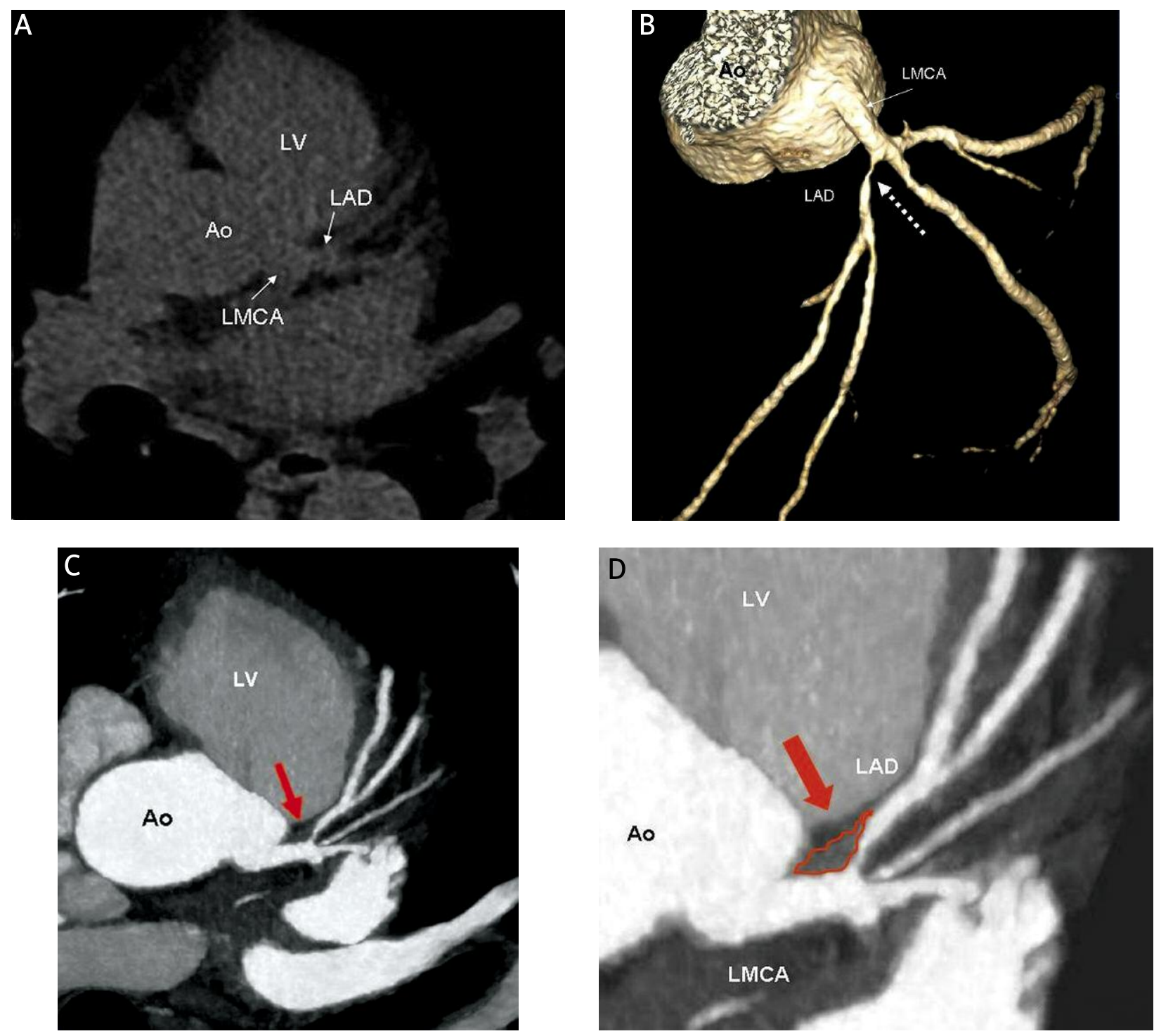

Fig. 3. The CAC score zero (negative coronary artery calcification) and high-grade proximal LAD stenosis presented in CCT angiography. The CAC score zero (A). Multiplanar reconstruction of LMCA and LAD reveals high-grade stenosis of proximal LAD (B, white dotted arrow) in the presence of zero CAC score (non-calcified plaque) (C, $D$ - red arrow) Ryc. 3. Indeks CAC zero (brak zwapnień w tętnicach wieńcowych) oraz istotne zwężenie proksymalnego odcinka LAD zobrazowane w angiografii CCT. Indeks CAC zero (A). Obecność istotnego zwężenia proksymalnego odcinka $\angle A D$ w wielopłaszczyznowej rekonstrukcji obrazu ( $B$, biata strzatka wykropkowana) u pacjenta z indeksem CAC zero (nieuwapniona blaszka miażdżycowa) (C, D-czerwona strzatka)

Table 3. After adjustment for age, gender, hypertension, hyperlipidemia, and creatinine levels, in both CAC score $\leq 10$ and $\leq 100$ groups, only age $(\mathrm{OR}=1.05,95 \% \mathrm{Cl}: 1.02-1.08, p=0.0005$, $\mathrm{OR}=1.05,95 \% \mathrm{Cl}: 1.03-1.08, p<0.0001$, respectively) and male gender $(\mathrm{OR}=3.45,95 \% \mathrm{Cl} ; 1.92-6.22, p<0.0001$, $\mathrm{OR}=3.31$, $95 \% \mathrm{Cl}: 1.88-5.81, p<0.0001$, respectively) were independent predictors of obstructive CAD.

\section{Discussion}

The first and most important finding of this study concerns the definition of low CAC score in an intermediate risk population. A total CAC score $\leq 10$, not as previously proposed $<100$, should be classified as a "low CAC score". A low CAC score or the absence of coronary calcifications does not mean the exclusion of coronary artery disease, as non-calcified obstructive coronary plaques might coexist with negative Agatston score results. Therefore CAC score $\leq 10$ better than CAC score $<100$ discriminates patients with lowcalcified or non-calcified obstructive plaque. Significant calcification might be interpreted as a kind of plaque stabilization. Consequently, patients with plaques richer in lipids, with more extensive inflammatory processes, with low cal- 
Table 3. Relation of cardiovascular risk factors to obstructive CAD in patients with CAC score $\leq 100$ and CAC score $\leq 10$ Tabela 3. Czynniki ryzyka wystąienia chorób sercowo-naczyniowych w przewidywaniu CAD w grupie chorych z indeksem $C A C \leq 100$ i indeksem $C A C \leq 10$

\begin{tabular}{|c|c|c|c|}
\hline \multirow[t]{2}{*}{ Parameter } & \multicolumn{3}{|c|}{ Univariate regression analysis } \\
\hline & $\overline{O R}$ & $95 \% \mathrm{Cl}$ & Value of $p$ \\
\hline \multicolumn{4}{|c|}{ CAC score $\leq 100(n=889)$} \\
\hline Age [year] & 1.05 & $1.03-1.07$ & $<0.0001$ \\
\hline Gender (male) & 2.01 & $1.40-2.91$ & 0.0002 \\
\hline Hypertension & 1.62 & $1.12-2.36$ & 0.0106 \\
\hline Hyperlipidemia & 1.49 & $1.03-2.15$ & 0.0329 \\
\hline Creatinine $[\mathrm{mmol} / \mathrm{l}]$ & 1.02 & $1.01-1.03$ & 0.0001 \\
\hline $\mathrm{HDL}(<1.15 \mathrm{mmol} / \mathrm{l})$ & 1.73 & $1.05-2.85$ & 0.0327 \\
\hline \multicolumn{4}{|c|}{ CAC score $\leq 10(n=668)$} \\
\hline Age [year] & 1.04 & $1.01-1.07$ & 0.0024 \\
\hline Gender (male) & 2.56 & $1.46-4.49$ & 0.010 \\
\hline Hypertension & 2.21 & $1.22-4.00$ & 0.0085 \\
\hline Hyperlipidemia & 1.78 & $1.01-3.15$ & 0.04 \\
\hline Creatinine $[\mathrm{mmol} / \mathrm{l}]$ & 1.03 & $1.01-1.04$ & 0.001 \\
\hline Fasting glucose level & 1.34 & $1.05-1.71$ & 0.0184 \\
\hline
\end{tabular}

cification or non-calcified, are at risk for plaque rupture. There is growing evidence suggesting that non-calcified plaque might be associated with acute coronary syndrome. An analysis of the composition of vulnerable plaques in acute coronary syndromes has shown that culprit lesions in $29 \%$ of cases were exclusively noncalcified. Thus, patients may develop symptomatic CAD or even acute coronary syndrome prior to the accumulation of calcium $[13,16]$. In more recent publications, the likelihood of obstructive coronary artery lesions in the absence of calcifications was considered to be in the range of $4 \%$ to as high as $29 \%$ [10, 17-21]. We conclude that the incidence of CAD in those studies was dependent mainly on the cut-off point of a low CAC score. In our analysis the incidence of CAD was two-fold higher (8.4\% vs. $15.7 \%$ ) when the criterion for a "low" CAC score was upgraded from an Agatston score of 10 to 100 . Importantly, when we compare patients with a CAC score of 10-100 to patients with a CAC score $\leq 10$, the incidence of CAD rises significantly ( $\sim 5$-fold). Our results are similar to the previous results of Ueda, who reported that the incidence of CAD increased 6-fold in the CAC 10-100 score group [22, 23]. When a CAC score $<100$ is classified as low, the high risk non-calcified obstructive CAD is simply overestimated.

The most important issue is to determine predictors of obstructive CAD with concomitant low CAC score. There have been several studies on the association between cardiovascular risk factors and the presence of non-obstructive calcified or non-calcified coronary plaque among patients with low CAC scores [10, 24-30]. The authors demonstrated that diabetes, hyperlipidemia, and smoking are associated with the presence of non-calcified, non-obstructive plaque, but the results for obstructive non-calcified plaque are not so obvious $[19,22,23]$. Similarly to our results, the multicenter CONFIRM Registry reported that male gender, age and smoking were independent predictors of CAD at negative CAC score results on CCT [30]. Traditional clinical risk factors, excluding age and gender, have no statistical power to be independent predictors of obstructive CAD among intermediate risk persons with low CAC scores.

\section{Conclusions}

The cut-off point of 10 for CAC score determined patients with CAD with the best sensitivity and specificity. Therefore, a total CAC score $<10$ should be classified as "low".

Low CAC score is associated with a low risk of obstructive CAD. Nevertheless, low CAC score alone cannot be used as a tool aimed at identifying or excluding obstructive CAD. In patients with low CAC scores obstructive plaques are present and are associated with increasing age and male gender. No additional clinical predictors of CAD in low CAC score patients were found.

\section{References}

1. Greenland P, Bonow RO, Brundage BH, et al. ACCF/AHA 2007 Clinical Expert Consensus Document on Coronary Artery Calcium Scoring by Computed Tomography in Global Cardiovascular Risk Assessment and in Evaluation of Patients With Chest Pain A Report of the American College of Cardiology. Circulation 2007; 115: 402-426.

2. Schroeder S, Achenbach S, Bengel F, et al. Working Group Nuclear Cardiology and Cardiac CT; European Society of Cardiology; European Council of Nuclear Cardiology. Cardiac computed tomography: indications, applications, limitations, and training requirements: report of a Writing Group deployed by the Working Group Nuclear Cardiology and Cardiac CT of the European Society of Cardiology and the European Council of Nuclear Cardiology. Eur Heart J 2008; 29: 531-556. 
3. Mark DB, Berman DS, Budoff MJ, et al. ACCF/ACR/AHA/NASCI/SAIP /SCAI/SCCT 2010 expert consensus document on coronary computed tomographic angiography: a report of the American College of Cardiology Foundation Task Force on Expert Consensus Documents. American College of Cardiology Foundation Task Force on Expert Consensus Documents. J Am Coll Cardiol 2010; 55: 2663-2699.

4. Sarwar A, Shaw L, Shapiro M, et al. Diagnostic and prognostic value of absence of coronary artery calcification. J Am Coll Cardiol Img 2009; 6: 675-688.

5. Greenland P, Alpert JS, Beller GA, et al. 2010 ACCF/AHA guideline for assessment of cardiovascular risk in asymptomatic adults: a report of the American College of Cardiology Foundation/American Heart Association Task Force on Practice Guidelines. J Am Coll Cardiol 2010; 56: e50-e103.

6. Kucukdurmaz Z, Sezen Y, Ulas T, et al. The relationship between the existence of angiographic coronary artery calcification and the severity of coronary artery disease. Postep Kardiol Inter 2012; 8: 91-5.

7. Hausleiter J, Meyer T, Hadamitzky M, et al. Prevalence of noncalcified coronary plaques by 64-slice computed tomography in patients with an intermediate risk for significant coronary artery disease. J Am Coll Cardiol 2006; 48: 312-318.

8. Schroeder S, Kuettner A, Kopp AF, et al. Noninvasive evaluation of the prevalence of noncalcified atherosclerotic plaques by multislice detector computed tomography: results of a pilot study. Int J Cardiol 2003; 92: 151-155.

9. Rubinshtein R, Gaspar T, Halon DA, et al. Prevalence and extent of obstructive coronary artery disease in patients with zero or low calcium score undergoing 64-slice cardiac multidetector computed tomography for evaluation of a chest pain syndrome. Am J Cardiol 2007; 99: 472-475.

10. Cheng VY, Lepor NE, Madyoon H, et al. Presence and severity of noncalcified coronary plaque on 64-slice computed tomographic coronary angiography in patients with zero and low coronary artery calcium. Am J Cardiol 2007; 99: 1183-1186.

11. Morita Ha, Fujimoto S, Kondo T, et al. Prevalence of computed tomographic angiography-verified high-risk plaques and significant luminal stenosis in patients with zero coronary calcium score. Int J Cardiol 2012; 158: 272-278.

12. Perk J, De Backer G, Gohlke H, et al. European Guidelines on cardiovascular disease prevention in clinical practice (version 2012). The Fifth Joint Task Force of the European Society of Cardiology and Other Societies on Cardiovascular Disease Prevention in Clinical Practice (constituted by representatives of nine societies and by invited experts). Developed with the special contribution of the European Association for Cardiovascular Prevention \& Rehabilitation (EACPR). Eur Heart J 2012; 33: 1635-1701.

13. Hoffmann U, Moselewski F, Nieman K, et al. Noninvasive assessment of plaque morphology and composition in culprit and stable lesions in acute coronary syndrome and stable lesions in stable angina by multidetector computed tomography. J Am Coll Cardiol 2006; 47: 1655-1662.

14. Pundziute G, Schuijf JD, Jukema JW, et al. Evaluation of plaque characteristics in acute coronary syndromes: non-invasive assessment with multi-slice computed tomography and invasive evaluation with intravascular ultrasound radiofrequency data analysis. Eur Heart J 2008; 29: 2373-2381.

15. Agatston AS, Janowitz WR, Hildner FJ, et al. Quantification of coronary artery calcium using ultrafast computed tomography. J Am Coll Cardiol 1990; 15: 827-832.

16. Fujii K, Kobayashi Y, Mintz GS, et al. Intravascular ultrasound assessment of ulcerated ruptured plaques: a comparison of culprit and nonculprit lesions of patients with acute coronary syndromes and lesions in patients without acute coronary syndromes. Circulation 2003; 108: 2473-2478.

17. Bluemke DA, Achenbach S, Budoff M, et al. Noninvasive Coronary Artery Imaging. Magnetic Resonance Angiography and Multidetector Computed Tomography Angiography. A Scientific Statement From the American Heart Association Committee on Cardiovascular Imaging and Intervention of the Council on Cardiovascular Radiology and Intervention, and the Councils on Clinical Cardiology and Cardiovascular Disease in the Young. Circulation 2008; 118: 586-606.

18. Gottlieb I, Miller JM, Arbab-Zadeh A, et al. The absence of coronary calcification does not exclude obstructive coronary artery disease or the need for revascularization in patients referred for conventional coronary angiography. J Am Coll Cardiol 2010; 55: 627-634.

19. Burgstahler C, Reimann A, Beck T, et al. Influence of a lipid-lowering therapy on calcified and noncalcified coronary plaques monitored by multislice detector computed tomography. Results of the New Age II Pilot Study. Invest Radiol 2007; 42: 189-195.

20. Akram K, O'Donnellb RE, King S, et al. Influence of symptomatic status on the prevalence of obstructive coronary artery disease in patients with zero calcium score. Atherosclerosis 2009; 203: 533-537.

21. Kelly JL, Thickman D, Abramson SD, et al. Coronary CT angiography findings in patients without coronary calcification. AJR Am J Roentgenol 2008; 191: 50-55.

22. Ueda H, Harimoto K, Tomoyama S, et al. Association between cardiovascular risk factors and the presence of coronary plaque in a zero or low coronary artery calcium score. Int I Cardiol 2011; 17: 475-477.

23. Ueda H, Harimoto K, Tomoyama S, et al. Relation of cardiovascular risk factors and angina status to obstructive coronary artery disease according to categorical coronary artery calcium score. Heart Vessels 2012; 27: 128-134.

24. Funabashi N, Asano M, Komuro I. Predictors of non-calcified plaques in the coronary arteries of 242 subjects using multislice computed tomography and logistic regression models. Int I Cardiol 2007; 117: 191-197.

25. Rivera JJ, Nasir K, Cox PR, et al. Association of traditional cardiovascular risk factors with coronary plaque sub-types assessed by 64-slice computed tomography angiography in a large cohort of asymptomatic subjects. Atherosclerosis 2009; 206: 451-457.

26. Sosnowski M, Pysz P, Szymański L, et al. Negative calcium score and the presence of obstructive coronary lesions in patients with intermediate CAD probability Int J Cardiol 2011; 148: e16-e18.

27. Alqarqaz M, Zaidan M, Al-Mallah MH. Prevalence and predictors of atherosclerosis in symptomatic patients with zero calcium score. Acad Radiol 2011; 18: 1437-1441

28. Hausleiter J, Meyer T, Hadamitzky M, et al. Prevalence of noncalcified coronary plaques by 64-slice computed tomography in patients with an intermediate risk for significant coronary artery disease. J Am Coll Cardiol 2006; 48: 312-318.

29. Bamberg F, Dannemann N, Shapiro MD, et al. Association between cardiovascular risk profiles and the presence and extent of different types of coronary atherosclerotic plaque as detected by multidetector computed tomography. Arterioscler Thromb Vasc Biol 2008; 28: 568-574.

30. Villines TC, Hulten AE, Shaw LJ, et al. Prevalence and severity of coronary artery disease and adverse events among symptomatic patients with coronary artery calcification scores of zero undergoing coronary computed tomography angiography results from the CONFIRM (Coronary CT Angiography Evaluation for Clinical Outcomes: An International Multicenter) Registry. JACC 2011; 58: 2533-2540. 